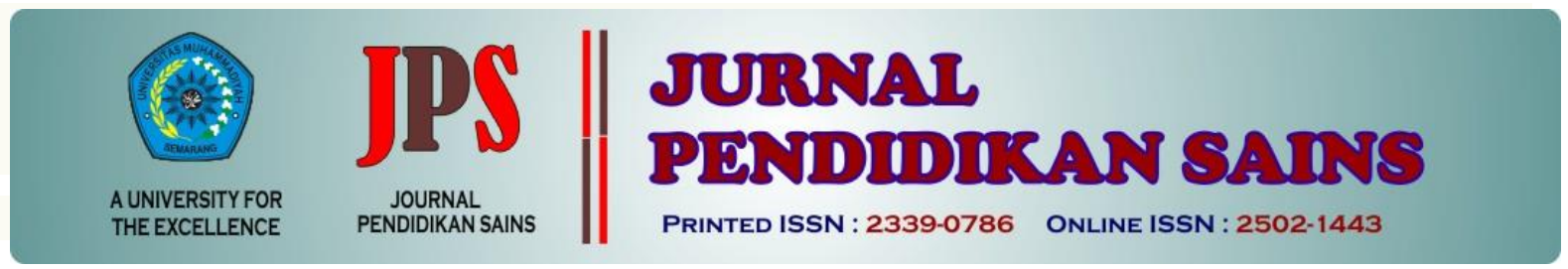

\title{
PENGEMBANGAN MEDIA SISCA YANG TERINTEGRASI WEB DAN BERORIENTASI GC UNTUK PEMBELAJARAN SMA-SMK DALAM PANDEMI COVID-19
}

\author{
Oleh : \\ Ina Yulianti ${ }^{*}$, Ida Hamidah ${ }^{2}$, Mumu Komaro ${ }^{3}$, Ahmad Mudzakir $^{4}$ \\ ${ }^{123}$ Program Studi Pendidikan Teknologi Kejuruan, Pasca Sarjana UPI, Indonesia \\ ${ }^{4}$ Program Studi Pendidikan Kimia, Universitas Pendidikan Indonesia (UPI), Indonesia \\ Jl. Dr. Setiabudi No. 229, Bandung, Jawabarat
}

\begin{tabular}{ll}
\hline Article history & Abstract \\
\hline $\begin{array}{l}\text { Submission }: 2020-04-29 \\
\text { Revised }\end{array}: 2020-06-19$ & $\begin{array}{l}\text { The pandemic in the Covid-19 era was directed at every online } \\
\text { integrated learning. The purpose of this research is to produce SISCA } \\
\text { Accepted }: 2020-07-06\end{array}$ \\
media that is integrated with web and oriented GC for high school and \\
vocational high school learning. This type of quantitative research uses \\
the Four-D (4D) model development method which is more focused \\
Kata kunci: Covid-19, \\
on development. Samples were taken by purposive sampling and \\
considered as research subjects, represented by high school and \\
vocational high school students. The research instrument, in the form \\
of a student response questionnaire, was used to collect data before \\
and after learning. The analysis technique uses a Likert scale, and the \\
results obtained using SISCA media on learning produce positive \\
changes with an average difference for the three aspects that are \\
responded to very significantly.
\end{tabular}

\section{Pendahuluan}

Ditengah merebaknya issu wabah covid-19 dimana setiap individu harus bisa menjaga jarak baik secara social distancing atau fisical distancing (Stein, 2020), pembelajaran pola daring (dalam jaringan) sangat tepat (Sung et al., 2018). Ketersediaan fasilitas jaringan internet untuk kondisi sekarang sangat penting dan utama supaya bisa tetap berinteraksi baik melalui media sosial atau video conference (Gella, Lewis, \& Rohrbach, 2020). Beruntungnya perkembangan teknologi informasi kini sangat mendukung terhadap situasi sulit ini. Setiap sekolah dituntut untuk tetap bisa menyelenggarakan pembelajaran walaupun tidak dengan tatap muka di kelas. Solusi yang paling tepat untuk menyikapi situasi ini yaitu pembelajaran harus dikondisikan dengan e-learning (Mayer, 2017).

Adanya kenyataan ini, menyebabkan transfer setiap materi pembelajaran harus dapat menyesuaikan dengan keadaan yang dianggap sebagai bencana nasional atau bahkan international. .

Berdasarkan analisis kebutuhan pada kondisi sekarang, maka perlu diciptakan pembelajaran yang melibatkan dukungan teknologi informasi secara penuh untuk keberlangsungan pembelajaran bahkan untuk meningkatkan hasil belajar. Tujuan penelitian ini adalah untuk menghasilkan media SISCA (Simulasi Interaktif Senyawa Carbon Aromatik) yang berorientasi GC (Green Chemistry) dan terintegrasi web untuk pembelajaran siswasiswi di SMA-SMK. Pengembangan media SISCA yang terintegrasi web (Kajaree \& Behera, 2017) dan berorientasi GC (Günter, Akkuzu, \& Alpat, 2017) dianggap tepat untuk dapat memenuhi kebutuhan pembelajaran saat ini.

\footnotetext{
*Corresponding Author:
Nama : Ina Yulianti
Lembaga : FPTK UPI Bandung, SMAN 3 Cimahi
Email : yuliantina@gmail.com




\section{Simulasi Interaktif}

Media SISCA, merupakan suatu aplikasi yang menampilkan metoda simulasi secara interaktif dalam pembelajaran yang terintegrasi web (Afolabi, Afolabi, Eshofonie, \& Akinbo, 2019), yang diakses secara daring. Kemajuan aksesibilitas dan kecanggihan teknologi, menyebabkan simulasi interaktif menjadi metoda yang menarik. Simulasi merupakan eksperimen dengan model, yaitu suatu teknik untuk menggantikan atau memperkuat pengalaman nyata dengan pengalaman yang dipandu secara interaktif. Menurut (Lee, Fried, \& Gibber, 2017), penggunaan simulasi dapat meningkatkan keterampilan dan memaksimalkan pengalaman. Simulasi sangat membantu pengembangan pengetahuan yang abstrak menjadi lebih nyata. Simulasi juga dapat membuat proses belajar menjadi lebih cepat, interaktif, terarah dan teratur. Pembelajaran menjadi lebih menarik, apalagi dengan terintegrasi web, siswa dapat lebih termotivasi untuk bisa berpikir kritis, kreatif, inovatif dan berkolaborasi dalam diskusi kelas maya. Simulasi dapat dikembangkan dan diimplementasikan ke dalam kurikulum, sehingga siswa akan mampu mengembangkan pengalamannya dalam menemukan teori/konsep

Keterampilan dalam menggunakan smartphone atau komputer yang didukung dengan fasilitas internet menjadi suatu kebutuhan yang mendesak. Bisa dimungkinan siswa yang tidak aktif pada pembelajaran konvensional berubah menjadi siswa yang proaktif pada pembelajaran simulasi terintegrasi web, karena siswa bisa mendapatkan feedback secara cepat dan langsung dari guru.

Penelitian yang berkaitan dengan simulasi interaktif yaitu, "Interactive Simulations to Support Quantum Mechanics Instruction for Chemistry Students", menjelaskan bahwa konsep mekanika kuantum sebagai dasar untuk memahami teori atom, struktur molekul, spektrum dan ikatan kimia diciptakan dengan maksud untuk mendukung pembelajaran melalui pengembangan interaksi interaktif berbasis riset (Kohnle, Baily, Campbell, Korolkova, \& Paetkau, 2015). Lebih dari 100 simulasi sudah tersedia secara bebas di situs web QuVis, yang dapat digunakan untuk pengajaran mandiri (Kohnle, Benfield, Hähner, \& Paetkau, 2017). Penelitian lainnya dengan judul "Using simulations to teach young students science concepts: An Experiential Learning theoretical analysis", memberikan gambaran bahwa simulasi dapat berlangsung secara efektif, dan dapat memberi kesempatan pada siswa untuk dapat terlibat dalam proses berpikir tingkat tinggi (Falloon, 2019). Kemampuan berpikir kritis dalam simulasi juga akan membuat siswa menjadi lebih aktif dalam mengkonstruksi pengetahuan (Aviana \& Hidayah, 2015)

\section{SISCA}

Tampilan media pembelajaran SISCA seperti terlihat pada Gambar 1, merupakan suatu aplikasi pembelajaran berupa web pembelajaran interaktif yang berisi materi cairan ion yang terbagi dalam menu Home, Materi, Vidio, Lembar Kerja Interaktif (LKI), Simulasi Interaktif (SISCA), dan evaluasi.

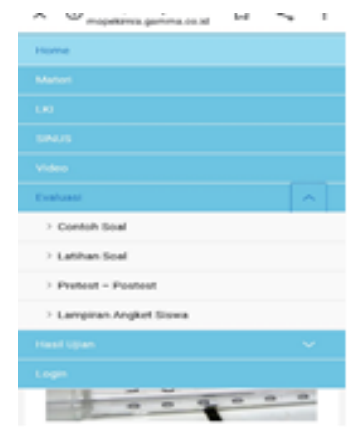

\section{Gambar 1. Tampilan Menu Media} Pembelajaran SISCA

Materi cairan ion merupakan perluasan dari materi senyawa karbon aromatik (Guedidi et al., 2020). Cairan ion merupakan material green berupa garam ionik cair pada suhu kamar (Wang et al., 2019). Media SISCA juga berisi data base yang memuat gugus-gugus rangkaian kation imidazolium dengan variasi beberapa anion sebagai penyusun cairan ion. Rangkaian gugus-gugus tadi digunakan untuk mensketsa struktur molekul cairan ion berupa garam ion imidazolium. SISCA juga memuat nilai titik leleh untuk masing-masing garam imidazolium.

SISCA merupakan pembaharuan dari aplikasi yang sudah ada sebelumnya, yaitu menggabungkan aplikasi Marvin Sketch (ChemAxon, 2013) dengan data melting point hasil observasi dan prediksi dari beberapa literatur dalam bentuk database (López-Martin, Burello, Davey, Seddon, \& Rothenberg, 2007)(Zhang, Sun, He, Lu, \& Zhang, 2006)(Kar, Tutusaus, MacFarlane, \& Mohtadi, 2019). Siswa dapat secara mandiri berlatih untuk menggambar atau membuat sketsa struktur molekul cairan ion yang diiginkan untuk mendapatkan informasi data melting 
point. Selanjutnya siswa dapat merefleksi pola keteraturan melting point dari variasi struktur molekul garam imidazolium yang sudah dibuat tadi kedalam suatu grafik show chart (LópezMartin et al., 2007) untuk membangun konsep/ teori.

Melalui grafik yang sudah dibentuk, selanjutnya siswa dapat mengekstrapolasi grafik tersebut untuk menentukan jenis cairan ion yang dapat digunakan pada suhu kamar dan dimanfaatkan untuk aplikasi tertentu. Kegiatan menggambar struktur, merefleksi, membangun konsep merupakan proses yang harus dilalui siswa sebagai pengalaman dalam pembelajaran (Kolb, Boyatzis, \& Mainemelis, 2014).

\section{Cairan Ion}

Cairan ion merupakan spesies yang netral terbentuk dari anion dan kation (Disasa Irge, 2016). Cairan ion sangat berbeda dengan garam ion atau senyawa ion biasa. Garam ion seperti $\mathrm{NaCl}$ berwujud padat pada suhu kamar dan hanya akan meleleh jika dipanaskan pada suhu melebihi $800^{\circ} \mathrm{C}$ (Afolabi et al., 2019). Hal ini membuat kondisi tidak praktis dan tidak menguntungkan untuk dapat digunakan, terutama untuk sintesis organik. Sebaliknya cairan ion memiliki suhu leleh dibawah $100^{\circ} \mathrm{C}$, dapat mencair pada suhu kamar, diatas suhu kamar atau bahkan di bawah suhu kamar sehingga sangat praktis dapat digunakan dalam berbagai keadaan suhu (Berthod, Ruiz-Ángel, \& Carda-Broch, 2018). Kation dan anion penyusun cairan ion yang biasa digunakan dalam analisis dan sintesis cairan ion diperlihatkan oleh Gambar 2.

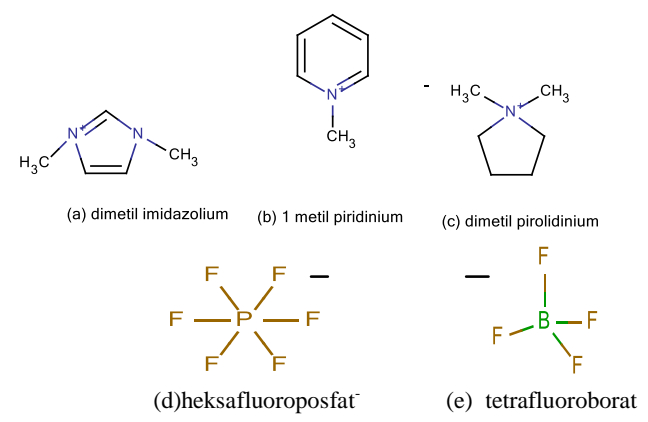

Gambar 2. Contoh Kation dan Anion Cairan Ion (Welton, 2018)

Cairan ion memiliki beberapa karakteristik yang luar biasa, yang membuatnya lebih disukai daripada jenis pelarut tradisional yang pernah ada sebelumnya, karena (1) Kemampuan solvating: zat terlarut dilarutkan oleh ion-ion pelarut cairan ion, sangat berbeda kondisinya dibandingkan dengan air atau pelarut organik biasa yang merupakan molekul netral; (2) Tidak ada/sedikit tekanan uap: tekanan uap cairan ion dapat diabaikan sehingga dapat meminimalkan paparan uap volatil beracun seperti pada pelarut organik; (3) Tidak mudah terbakar; (4) Stabilitas termal, kimia, dan elektrokimia yang tinggi; (5) Rentang cairan besar : rentang suhu antara cair besar; (6) Mudah didaur ulang; (7) Sangat polar; (8) non coordinating; (9) Tunable miscibility with water and other organic solvant; (10) Cairan ionik kiral dapat mengontrol stereoselektivitas; (11) Memiliki masa simpan lebih lama; (12) memiliki daya konduksi (Disasa Irge, 2016). Jenis cairan ion yang berwujud cair pada temperatur kamar (Room Temperature Ionic iquid/RTIL), telah menjadi fokus perhatian.

Jenis kation dapat menentukan densitas, viskositas, dan sifat lipofilik atau hidrofilik suatu cairan ion. Semakin panjang rantai alkil, maka viskositas akan semakin tinggi. Sifat hidrofobik/lipofilik cairan ion juga meningkat dengan semakin panjangnya rantai alkil (Papović, Bešter-Rogač, Vraneš, \& Gadžurić, 2016). Sedangkan, jenis anion dapat menentukan sifat asam, basa atau netral suatu cairan ion.

Penyediaan media solvasi untuk reaksi kimia dan menciptakan proses reaksi yang ramah lingkungan merupakan upaya terbaru untuk menggantikan pelarut tradisional (Disasa Irge, 2016). Setiap proses kimia dan sintesis bahan, media reaksi selalu dalam fasa cair. Ketersediaan mudah, tidak mudah terbakar, tidak beracun, dan ramah lingkungan adalah manfaat dari air sebagai pelarut (Mannekote, Kailas, Venkatesh, \& Kathyayini, 2018). Namun, penggunaan media air sebagai pelarut terhambat untuk rentang suhu cairan yang terbatas yaitu hanya kisaran $0-100^{\circ} \mathrm{C}$. Selain itu, beberapa pelarut organik bersifat eksplosif, mudah terbakar dan beracun sedangkan cairan ion merupakan pelarut green (Khandelwal, Tailor, \& Kumar, 2016).

Pengembangan media pembelajaran SISCA dianggap urgent untuk dapat dirancang dan digunakan pada tingkat SMA-SMK sebagai acuan pengetahuan dasar dalam proses kimia terutama dalam penggunaan pelarut yang green (Yulianti, Hamidah, \& Komaro, 2020).

\section{Metode Penelitian}

Metoda penelitian yang digunakan adalah metoda riset dan pengembangan model Four-D (4D) dengan tahapan pendefinisian, 
perancangan, pengembangan dan penyebaran. Tetapi penelitian ini lebih memfokuskan pada tahap pengembangan.

\section{Jenis Penelitian}

Penelitian ini termasuk jenis penelitian kuantitatif, yaitu mengolah data secara kuantitatif berdasarkan hasil kuesioner sebelum dan sesudah pembelajaran.

\section{Waktu dan Tempat Penelitian}

Penelitian dilakukan pada bulan Maret 2020 ketika wabah Covid-19 sedang pandemi. Tempat penelitian yang pada awal rencana akan dilakukan di sekolah masing-masing, tetapi dengan mewabahnya Covid-19 menyebabkan pengambilan data penelitian dilakukan di rumah masing-masing (WFH) responden secara daring (Bloom, Liang, Roberts, \& Ying, 2015).

\section{Target/Subjek Penelitian}

Target/subjek penelitian merupakan sampel penelitian yang diambil secara purposive sampling, yaitu Siswa-siswi SMA dan SMK masing-masing sebanyak 10 orang.

\section{Prosedur}

Prosedur penelitian mengikuti tahapan model four-D, tetapi lebih difokuskan pada tahap pengembangan seperti terlihat pada Gambar 3.

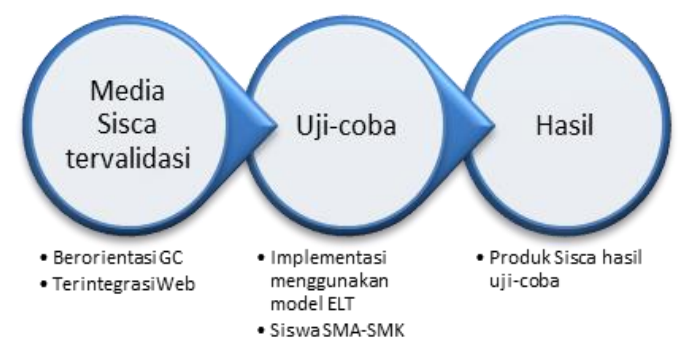

Gambar 3. Tahap pengembangan Model four-D diadopsi dari (Lawhon, 1976)

Media SISCA yang telah dirancang, kemudian diimplementasikan melalui tahapan pembelajaran yang menekankan pada pengalaman siswa, mengacu pada siklus pengalaman belajar Eksperience Learning Theory (ELT) pada Gambar 4.

Implementasi dilakukan sebanyak 2 kali pertemuan untuk 1 siklus. Tahap ke-1 dan ke-2 yaitu concrete eksperience dan reflective observation dilaksanakan pada pertemuan pertama, sedangkan tahap ke-3 dan ke-4 yaitu postes dan mengisi kuesioner kembali dalam menu evaluasi. abstract conzeptualitation dan active eksperiment dilaksanakan pada pertemuan kedua.

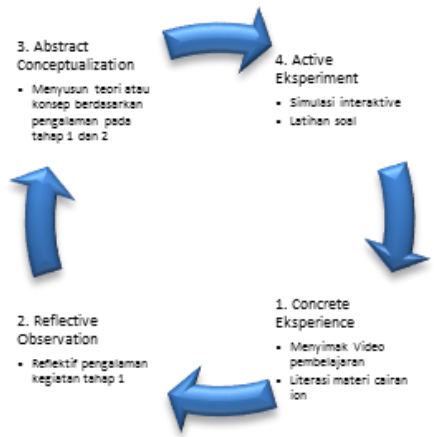

Gambar 4. Implementasi produk web melalui siklus pengalaman belajar (Tomkins \& Ulus, 2015)

Sebelum dilaksanakan implementasi pengembangan pembelajaran penggunaan web, terlebih dahulu dilakukan pengisian kuesioner awal (kues 1) dan pretes. Kemudian setelah ujicoba selesai dilanjutkan dengan pengisian kuesioner akhir (kues 2) serta postes. Apersepsi dan tujuan pembelajaran disampaikan secara online melalui kelas maya grup whatsapp, sebelum pelaksanaan siklus. Kegiatan siswa diawali dengan membuka laptop/smartphone masing-masing, mencari tautan web pembelajaran mopekimia.gamma.co.id lalu mengisi kues 1 dan pretes. Setelah itu pembelajaran dimulai berdasarkan urutan tahapan pada siklus.

Pada pertemuan pertama tahap ke-1 yaitu concret eksperience, responden diberikan pengalaman untuk menyimak video pembelajaran dan materi cairan ion melalui website tadi. Kemudian tahap ke-2 yaitu merefleksi hasil dari kegiatan tahap ke-1 dan melakukan diskusi dalam kelas maya dengan dipandu oleh guru. Pada pertemuan kedua, untuk tahap ke-3 abstract conzeptualization, masing-masing responden menyusun konsep cairan ion berdasarkan hasil kegiatan pada tahap ke-1 dan 2. Pada tahap ini responden bisa menambah pengetahuan cairan ion melalui diskusi atau dengan membuka tautan lain untuk memperkaya pengetahuan. Pada tahap ke-4, responden melakukan simulasi interaktif SISCA melalui website mopekimia.gamma.co.id dengan dipandu guru. Kemudian mengerjakan soal essai dan pilihan ganda dengan feedback langsung, supaya pemahaman siswa menjadi lebih terarah. Setelah selesai, siswa mengikuti 
Data, Intrumen, dan Teknik Pengumpulan Data

Data yang diperoleh merupakan respon responden terhadap media SISCA berupa tampilan web, cara menyajikan materi dalam web dan sikap responden terhadap penggunaan web yang direkap dalam instrumen berupa kuesioner yang telah divalidasi sebelumnya. Hasil validasi instrumen pada studi pendahuluan untuk validator ahli materi mencapai skor 80,16\% dengan kategori cukup valid dan untuk ahli media mencapai skor $92,20 \%$ dengan kategori sangat valid. Jika dirata-ratakan total skor mencapai $86,16 \%$ dengan kategori sangat valid, hal ini dapat diasumsikan bahwa instrumen layak untuk digunakan (Rawa, Sutawidjaja, \& Sudirman, 2016).

Teknik pengumpulan data dilakukan responden dengan memilih salah satu dari 4 option yang dianggap paling sesuai dengan kondisi media SISCA yang sedang dikembangkan, dengan rentang skala Likert yaitu SS (sangat setuju), S (setuju), KS (kurang setuju) dan TS (tidak setuju) dengan masingmasing bernilai secara berurutan 4, 3, 2 dan 1 (Joshi, Kale, Chandel, \& Pal, 2015).

Walaupun pada penelitian ini terdapat data lain yaitu hasil pretes-postes, akan tetapi yang dipertajam pada artikel ini hanya menyoroti hasil kusioner awal dan akhir.

\section{Teknik Analisis Data}

Data yang sudah terkumpul melalui kuesioner awal dan akhir tadi kemudian diolah dengan cara menghitung rata-rata respon untuk setiap pernyataan dalam aspek dari kedua kelompok responden tersebut. Kemudian menghitung pula rata-rata total respon untuk setiap responden dalam setiap kelompok, selanjutnya diinterpretasi untuk bisa ditarik kesimpulan. Jika nilai respon berkisar antara 3,21-4,00 maka mencapai kategori sangat baik, nilai antara 2,41-3,20 berkategori baik, 1,612,40 kategori tidak baik dan 0,00-0,80 mencapai kategori sangat tidak baik (Desmawati, 2010).

\section{Hasil Penelitian dan Pembahasan}

Hasil pengolahan kuesioner respon siswa-siswi SMA dan SMK terhadap pernyataan-pernyataan pada aspek tampilan, penyajian materi dan sikap diperlihatkan Tabel 1.
Berdasarkan hasil pengolahan data pada Tabel 1, rata-rata nilai tampilan untuk responden SMA sebesar 3,18 dengan kategori B (baik) dan 3,35 untuk responden SMK dengan kategori SB (sangat baik). Respon tampilan untuk responden SMK lebih tinggi dibanding dengan responden SMA. Terdapat perbedaan yang sangat signifikan dengan selisih hanya 0,17 . Perbedaan ini disebabkan karena respon responden SMK pada pernyataan 2 mengenai "Letak tombol, teks, gambar teratur" dan pernyataan 4 mengenai "Jenis, ukuran dan spasi huruf sesuai sehingga terbaca dengan jelas" memperoleh nilai 3,6 dan 3,8 dibandingkan dengan nilai responden SMA hanya 3,3 dan 3,2. Walaupun begitu, media SISCA sudah bisa/layak digunakan karena penilaian kedua kelompok B dan SB.

Pada aspek penyajian materi, perolehan rata-rata respon responden SMA sebesar 3,02 dan responden SMK 3,14, keduanya berkategori B. Responden SMK memberikan respon yang sedikit lebih tinggi yaitu 0,12 , hal ini disebabkan karena pernyataan 8 mengenai "Materi yang disajikan menarik dan mudah dipahami" dan pernyataan 13 mengenai "Pembahasan pada latihan soal mudah dipahami" responden SMA hanya memberikan respon 2,7 dan 2,8, sementara responden SMK memberikan respon 3,1. Kedua kelompok responden memberikan respon penilaian berkategori "B", akan tetapi karena penilaian responden SMA kurang dari 3,0 maka akan diberikan penguatan lagi pada bagian penyajian materi dan pembahasan soal. Untuk aspek sikap, penilaian rata-rata respon responden SMA sebesar 3,11 dan SMK 3,17. Nilai yang hampir sama, tetapi respon penilaian responden SMK sedikit lebih tinggi dibanding SMA, hal ini salah satunya karena penilaian pada pernyataan 28 mengenai "Pemberian skor dalam soal tes menunjukkan sejauh mana kemampuan dalam mahami materi cairan ion". Sebanyak 2 siswa SMA merespon kurang setuju, karena menurut pendapatnya, media SISCA tidak memunculkan nilai langsung setelah mereka submit. Padahal sebetulnya, semua hasil nilai dapat dilihat oleh setiap responden pada menu evaluasi dengan sub menu rekapan evaluasi. Informasi ini tidak tersampaikan pada saat pengambilan data, oleh karenanya ini akan menjadi catatan untuk pengembangan media SISCA lebih lanjut. 
Tabel 1. Hasil Kuesioner Respon Responden untuk Setiap Pernyataan

\begin{tabular}{|c|c|c|c|c|c|}
\hline \multirow{2}{*}{ No } & \multirow{2}{*}{ Pernyataan } & \multicolumn{2}{|c|}{ SMA } & \multicolumn{2}{|c|}{ SMK } \\
\hline & & Nilai & Kategori & Nilai & Kategori \\
\hline \multicolumn{6}{|c|}{ A.Tampilan } \\
\hline 1 & Tampilan awal menu utama menarik & 3,3 & SB & 3,2 & B \\
\hline 2 & Letak tombol, teks, gambar teratur & 3,3 & SB & 3,6 & SB \\
\hline 3 & $\begin{array}{l}\text { Desain background menarik, komposisi warna } \\
\text { sesuai sehingga tidak mengganggu pembacaan } \\
\text { teks atau gambar }\end{array}$ & 3,2 & $\mathrm{~B}$ & 3,2 & B \\
\hline 4 & $\begin{array}{l}\text { Jenis, ukuran dan spasi huruf sesuai sehingga } \\
\text { terbaca dengan jelas }\end{array}$ & 3,2 & $\mathrm{~B}$ & 3,8 & SB \\
\hline 5 & $\begin{array}{l}\text { Tombol mudah dikenali dan mudah } \\
\text { dioperasikan }\end{array}$ & 3 & $\mathrm{~B}$ & 3,2 & B \\
\hline 6 & Perpaduan warna isi media sudah tepat & 3,1 & $\mathrm{~B}$ & 3,1 & B \\
\hline & Jumlah Rata-rata & 3,18 & $\mathrm{~B}$ & 3,35 & SB \\
\hline \multicolumn{6}{|c|}{ B. Penyajian Materi } \\
\hline 7 & $\begin{array}{l}\text { Petunjuk penggunaan media pembelajaran } \\
\text { SISCA jelas }\end{array}$ & 3 & B & 3,3 & SB \\
\hline 8 & $\begin{array}{l}\text { Materi yang disajikan menarik dan mudah } \\
\text { dipahami }\end{array}$ & 2,7 & B & 3,1 & B \\
\hline 9 & Susunan materi yang disajikan runtut & 3,2 & $\mathrm{~B}$ & 3,3 & SB \\
\hline 10 & $\begin{array}{l}\text { Gambar terlihat jelas sehingga membantu } \\
\text { pemahaman }\end{array}$ & 3 & $\mathrm{~B}$ & 3 & $\mathrm{~B}$ \\
\hline 11 & $\begin{array}{l}\text { Video terlihat jelas dan mendukung materi } \\
\text { pembelajaran }\end{array}$ & 3 & B & 3 & $\mathrm{~B}$ \\
\hline 12 & Bahasa yang digunakan komunikatif & 3,3 & SB & 2,9 & $\mathrm{~B}$ \\
\hline 13 & $\begin{array}{l}\text { Pembahasan pada latihan soal mudah dipahami, } \\
\text { sehingga bisa memperkuat pemahaman }\end{array}$ & 2,8 & $\mathrm{~B}$ & 3,1 & $\mathrm{~B}$ \\
\hline 14 & $\begin{array}{l}\text { Petunjuk untuk mengerjakan soal jelas dan } \\
\text { dapat dipahami }\end{array}$ & 3,1 & $\mathrm{~B}$ & 3,3 & SB \\
\hline 15 & $\begin{array}{l}\text { Adanya umpan balik membantu saya dalam } \\
\text { menemukan konsep yang benar }\end{array}$ & 3 & B & 3,3 & SB \\
\hline & Jumlah Rata-rata & 3,02 & $\mathrm{~B}$ & 3,14 & $\mathrm{~B}$ \\
\hline \multicolumn{6}{|c|}{ C. Sikap } \\
\hline 16 & Media pembelajaran SISCA sangat bermanfaat & 3,4 & SB & 3,4 & SB \\
\hline 17 & $\begin{array}{l}\text { Saya merasa tertarik dan termotivasi, } \\
\text { menggunakan media pembelajaran ini }\end{array}$ & 2,9 & B & 3 & $\mathrm{~B}$ \\
\hline 18 & Saya memahami tujuan pembelajaran media ini & 2,9 & $\mathrm{~B}$ & 2,9 & $\mathrm{~B}$ \\
\hline 19 & $\begin{array}{l}\text { Belajar dengan SISCA membuat saya lebih } \\
\text { terampil IT }\end{array}$ & 3,1 & B & 3 & $\mathrm{~B}$ \\
\hline 20 & $\begin{array}{l}\text { Belajar dengan SISCA mendorong saya untuk } \\
\text { menemukan ide-ide baru }\end{array}$ & 3,1 & $\mathrm{~B}$ & 3,3 & SB \\
\hline 21 & $\begin{array}{l}\text { Belajar dengan SISCAs dapat mengeksplorasi } \\
\text { diri sendiri }\end{array}$ & 3,4 & SB & 3,2 & B \\
\hline 22 & $\begin{array}{l}\text { Belajar dengan SISCA melatih saya untuk } \\
\text { berinteraktif }\end{array}$ & 3,3 & SB & 3 & B \\
\hline 23 & $\begin{array}{l}\text { Belajar dengan SISCA membuat materi lebih } \\
\text { mudah diingat }\end{array}$ & 2,8 & B & 3 & B \\
\hline 24 & $\begin{array}{l}\text { Saya setuju media pembelajaran SISCA } \\
\text { digunakan di sekolah dan dimasukkan dalam } \\
\text { silabus }\end{array}$ & 2,8 & B & 3,2 & B \\
\hline 25 & $\begin{array}{l}\text { Pembelajaran dengan SISCA lebih efektif dan } \\
\text { efisien }\end{array}$ & 3,2 & B & 3,2 & B \\
\hline 26 & $\begin{array}{l}\text { Mengikuti pembelajaran SISCA merupakan hal } \\
\text { yang baru bagi saya }\end{array}$ & 3,5 & SB & 3,6 & SB \\
\hline 27 & $\begin{array}{l}\text { Belajar dengan media pembelajaran SISCA ini, } \\
\text { menjadikan saya paham akan konsep green } \\
\text { cairan ionik. }\end{array}$ & 3,1 & B & 3 & B \\
\hline
\end{tabular}




\begin{tabular}{clcccc}
\hline 28 & $\begin{array}{l}\text { Pemberian skor dalam soal tes menunjukan } \\
\text { sejauh mana kemampuan saya dalam memahami } \\
\text { materi cairan ionik }\end{array}$ & 2,9 & B & 3,4 & SB \\
\hline Jumlah Rata-rata & 3,11 & B & 3,17 & B \\
\hline
\end{tabular}

Nilai rata-rata total respon untuk kelompok responden SMA sebesar 3,10 dan SMK sebesar 3,22. Jadi secara keseluruhan nilai rata-rata respon kelompok responden SMK lebih tinggi dibandingkan dengan SMA, seperti terlihat pada Tabel 2 .

Tabel 2. Perolehan nilai rata-rata untuk setiap aspek dan keseluruhan aspek

\begin{tabular}{ccccc}
\hline Aspek & SMA & Kategori & SMK & Kategori \\
\hline A. Tampilan & 3,18 & B & 3,35 & SB \\
$\begin{array}{c}\text { B. Penyajian } \\
\text { Materi }\end{array}$ & 3,02 & B & 3,14 & B \\
$\begin{array}{c}\text { C. Sikap } \\
\text { Rata-rata } \\
\text { Total }\end{array}$ & 3,11 & B & 3,17 & B \\
\hline
\end{tabular}

Untuk melihat perbandingan nilai respon responden SMA dan SMK untuk ketiga aspek dapat dilihat pada Gambar 5.

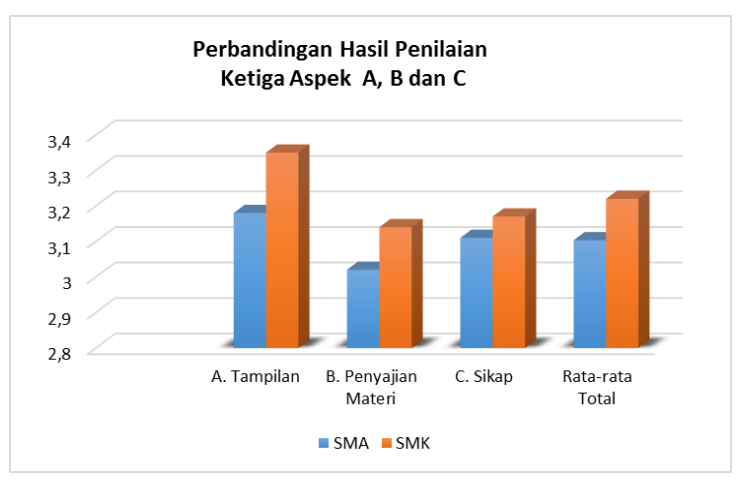

Gambar 5. Perbandingan Hasil Penilaian Ketiga Aspek A, B dan C.

Berdasarkan grafik perbandingan ketiga aspek tampilan, penyajian materi dan sikap, responden SMK memberikan respon yang lebih positif dibandingkan dengan SMA, sehingga nilai rata-rata total secara keseluruhan respon kelompok responden SMK memberikan nilai tertinggi dibanding SMA. Walaupun begitu kedua kelompok responden memberikan respon kategori "B", berarti pembelajaran media SISCA yang terintegrasi web dan berorientasi Green Chemistry dapat diterapkan/layak digunakan di sekolah menengah.

Jika dianalisis dari sudut respon tiap responden seperti terlihat pada Tabel 3, Kedua kelompok menunjukkan respon kategori "setuju" dengan perolehan rata-rata nilai respon 77,2 untuk kelompok SMA dan 79,6 untuk kelompok SMK. Perolehan nilai tertinggi pada kelompok SMK, hal ini disebabkan penilaian respon kelompok SMA memiliki nilai terendah 67,9 sebanyak 2 responden dan tertinggi 85,7 sebanyak 2 responden. Sedangkan untuk tingkat SMK nilai terendah sedikit lebih tinggi dari SMA yaitu 74,1 sebanyak 1 responden dan tertinggi 87,5 sebanyak 2 responden. Kemudian seluruh siswa SMA memilih option setuju sebanyak 197 pernyataan atau 70,4\% dari 28 pernyataan dan 10 responden, sangat setuju 55 atau $19,6 \%$.

\begin{tabular}{|c|c|c|c|c|c|c|}
\hline \multirow{2}{*}{$\begin{array}{c}\text { Respon } \\
\text { den }\end{array}$} & \multicolumn{4}{|c|}{ Nilai Respon } & \multirow{2}{*}{$\begin{array}{l}\text { Total } \\
\text { Nilai } \\
\end{array}$} & \multirow{2}{*}{$\begin{array}{l}\text { Kate } \\
\text { gori }\end{array}$} \\
\hline & 1 & 2 & 3 & 4 & & \\
\hline \multicolumn{7}{|l|}{ SMA } \\
\hline 1 & & & 19 & 9 & 83,0 & $S$ \\
\hline 2 & & & 27 & 1 & 75,9 & S \\
\hline 3 & & & 16 & 12 & 85,7 & S \\
\hline 4 & & 1 & 20 & 7 & 80,4 & S \\
\hline 5 & 1 & 11 & 11 & 5 & 67,9 & S \\
\hline 6 & 1 & 9 & 15 & 3 & 67,9 & S \\
\hline 7 & & & 24 & 4 & 78,6 & S \\
\hline 8 & & & 28 & & 75,0 & S \\
\hline 9 & & 5 & 21 & 2 & 72,3 & S \\
\hline 10 & & & 16 & 12 & 85,7 & $\mathrm{~S}$ \\
\hline Jumlah & 2 & 26 & 197 & 55 & \multirow{2}{*}{77,2} & \multirow{2}{*}{$S$} \\
\hline$\%$ & 0,7 & 9,3 & 70,4 & 19,6 & & \\
\hline \multicolumn{7}{|l|}{ SMK } \\
\hline 1 & & 1 & 27 & & 74,1 & $S$ \\
\hline 2 & & 1 & 25 & 2 & 75,9 & S \\
\hline 3 & 1 & 4 & 14 & 9 & 77,7 & S \\
\hline 4 & & 3 & 16 & 9 & 80,4 & $S$ \\
\hline 5 & & & 14 & 14 & 87,5 & S \\
\hline 6 & & & 14 & 14 & 87,5 & S \\
\hline 7 & & 4 & 21 & 3 & 74,1 & S \\
\hline 8 & & 2 & 17 & 9 & 81,3 & S \\
\hline 9 & & & 28 & & 75,0 & $S$ \\
\hline 10 & & & 19 & 9 & 83,04 & \\
\hline Jumlah & 1 & 15 & 195 & 69 & \multirow{2}{*}{79,6} & \multirow{2}{*}{$S$} \\
\hline$\%$ & 0,4 & 5,4 & 69,6 & 24,6 & & \\
\hline
\end{tabular}


Sedangkan untuk 10 siswa SMK memilih option setuju 195 pernyataan atau $69,6 \%$ dan sangat setuju 69 atau $24,6 \%$.

Walaupun begitu, karena setiap responden rata-rata memberikan respon "S (setuju)" untuk setiap pernyataan-pernyataan pada ketiga aspek tersebut, maka media SISCA yang dikembangkan layak untuk bisa digunakan di SMA-SMK

\section{Simpulan dan Saran}

\section{Simpulan}

Pengembangan media SISCA yang terintegrasi web dan berorientasi Green Chemistry dapat diterapkan di SMA-SMK dapat dibuktikan dari hasil respon seluruh responden terhadap setiap peryataan aspek tampilan, penyajian materi dan sikap berkategori "baik" atau "sangat baik". Setiap responden siswa SMA dan SMK memberikan respon kategori "setuju" terhadap seluruh pernyataan yang berkaitan dengan pengembangan media SISCA. Akan tetapi diperlukan perulangan siklus pembelajaran untuk mencapai hasil yang lebih baik dan diperlukan guru sebagai pendamping pembelajaran.

\section{Saran}

Pembelajaran berbasis e-learing khususnya website, disarankan tidak hanya digunakan untuk saat pandemi Covid-19 sekarang saja, tetapi harus dikembangkan lagi lebih lanjut. Rekomendasi untuk pemangku kebijakan kurikulum baik tingkat pusat atau daerah, untuk dapat memasukan materi cairan ion kedalam kurikulum sekolah menengah sebagai muatan teknologi material yang green.

\section{Ucapan Terima Kasih}

Ucapan terimakasih disampaikan kepada Dinas Pendidikan Provinsi Jawa Barat yang sudah memberikan kontribusi dalam penelitian ini, dalam bentuk Hibah Riset Pegawai.

\section{Daftar Pustaka}

Afolabi, A., Afolabi, I., Eshofonie, E., \& Akinbo, F. (2019). Improving Employability Skills Through a WebBased Work Integrated Learning Database for Construction Students. In Lecture Notes in Computer Science (including subseries Lecture Notes in Artificial Intelligence and Lecture Notes in
Bioinformatics).

https://doi.org/10.1007/978-3-030-243081_31

Aviana, R., \& Hidayah, F. (2015). Pengaruh Tingkat Konsentrasi Belajar Siswa Terhadap Daya Pemahaman Materi pada Pembelajaran Kimia di SMA Negeri 2 Batang. Jurnal Pendidikan Sains Universitas Muhammadiyah Semarang. https://doi.org/10.26714/jps.3.1.2015.3033

Berthod, A., Ruiz-Ángel, M. J., \& Carda-Broch, S. (2018). Recent advances on ionic liquid uses in separation techniques. Journal of Chromatography $A$. https://doi.org/10.1016/j.chroma.2017.09. 044

Bloom, N., Liang, J., Roberts, J., \& Ying, Z. J. (2015). Does working from home work? Evidence from a chinese experiment. Quarterly Journal of Economics. https://doi.org/10.1093/qje/qju032

ChemAxon. (2013). Marvin Sketch.

Desmawati, Y. (2010). Pengembangan Media Compact Disc (CD) pada Pembelajaran IPA Biologi Pokok Bahasan Sistem Reproduksi Manusia di Sekolah Menengah Pertama (SMP) Islam Terpadu Raudhatul Ulum Sakatiga Kabupaten Ogan Ilir. Tesis. Universitas Sriwijaya Palembang.

Disasa Irge, D. (2016). Ionic Liquids: A Review on Greener Chemistry Applications, Quality Ionic Liquid Synthesis and Economical Viability in a Chemical Processes. American Journal of Physical Chemistry. https://doi.org/10.11648/j.ajpc.20160503.1 4

Falloon, G. (2019). Using simulations to teach young students science concepts: An Experiential Learning theoretical analysis. Computers and Education. https://doi.org/10.1016/j.compedu.2019.03 .001

Gella, S., Lewis, M., \& Rohrbach, M. (2020). A dataset for telling the stories of social media videos. In Proceedings of the 2018 Conference on Empirical Methods in Natural Language Processing, EMNLP 2018. 
Guedidi, H., Lakehal, I., Reinert, L., Lévêque, J. M., Bellakhal, N., \& Duclaux, L. (2020). Removal of ionic liquids and ibuprofen by adsorption on a microporous activated carbon: Kinetics, isotherms, and pore sites. Arabian Journal of Chemistry. https://doi.org/10.1016/j.arabjc.2017.04.0 06

Günter, T., Akkuzu, N., \& Alpat, Ş. (2017). Understanding 'green chemistry' and 'sustainability': an example of problembased learning (PBL)*. Research in Science and Technological Education. https://doi.org/10.1080/02635143.2017.13 53964

Joshi, A., Kale, S., Chandel, S., \& Pal, D. (2015). Likert Scale: Explored and Explained. British Journal of Applied Science \& Technology. https://doi.org/10.9734/bjast/2015/14975

Kajaree, D., \& Behera, R. N. (2017). A Survey on Web Crawler Approaches. International Journal of Innovative Research in Computer and Communication Engineering. https://doi.org/10.15680/IJIRCCE.2017.

Kar, M., Tutusaus, O., MacFarlane, D. R., \& Mohtadi, R. (2019). Novel and versatile room temperature ionic liquids for energy storage. Energy and Environmental Science. https://doi.org/10.1039/c8ee02437e

Khandelwal, S., Tailor, Y. K., \& Kumar, M. (2016). Deep eutectic solvents (DESs) as eco-friendly and sustainable solvent/catalyst systems in organic transformations. Journal of Molecular Liquids. https://doi.org/10.1016/j.molliq.2015.12.0 15 Review

Kohnle, A., Baily, C., Campbell, A., Korolkova, N., \& Paetkau, M. J. (2015). Enhancing student learning of two-level quantum systems with interactive simulations. American Journal of Physics. https://doi.org/10.1119/1.4913786

Kohnle, A., Benfield, C., Hähner, G., \& Paetkau, M. (2017). Interactive Simulations to Support Quantum Mechanics Instruction for Chemistry Students. Journal of Chemical Education. https://doi.org/10.1021/acs.jchemed.6b004 59
Kolb, D. A., Boyatzis, R. E., \& Mainemelis, C. (2014). Experiential learning theory: Previous research and new directions. In Perspectives on Thinking, Learning, and Cognitive Styles. https://doi.org/10.4324/9781410605986-9

Lawhon, D. (1976). Instructional development for training teachers of exceptional children: A sourcebook. Journal of School Psychology. https://doi.org/10.1016/00224405(76)90066-2

Lee, A. Y., Fried, M. P., \& Gibber, M. (2017). Improving Rhinology Skills with Simulation. Otolaryngologic Clinics of North America. https://doi.org/10.1016/j.otc.2017.05.002

López-Martin, I., Burello, E., Davey, P. N., Seddon, K. R., \& Rothenberg, G. (2007). Anion and cation effects on imidazolium salt melting points: A descriptor modelling study. ChemPhysChem. https://doi.org/10.1002/cphc.200600637

Mannekote, J. K., Kailas, S. V., Venkatesh, K., \& Kathyayini, N. (2018). Environmentally friendly functional fluids from renewable and sustainable sources-A review.

Renewable and Sustainable Energy Reviews. https://doi.org/10.1016/j.rser.2017.05.274

Mayer, R. E. (2017). Using multimedia for elearning. Journal of Computer Assisted Learning. https://doi.org/10.1111/jcal.12197

Papović, S., Bešter-Rogač, M., Vraneš, M., \& Gadžurić, S. (2016). The effect of the alkyl chain length on physicochemical features of (ionic liquids $+\gamma$ butyrolactone) binary mixtures. Journal of Chemical Thermodynamics. https://doi.org/10.1016/j.jct.2016.03.034

Rawa, N., Sutawidjaja, A., \& Sudirman, S. (2016). Pengembangan Perangkat Pembelajaran Berbasis Model Learning Cycle 7E Pada Materi Trigonometri Untuk Meningkatkan Kemampuan Koneksi Matematis Siswa. Jurnal Pendidikan Teori, Penelitian, Dan Pengembangan. https://doi.org/10.17977/jp.v1i6.6368

Stein, R. (2020). COVID-19 and Rationally Layered Social Distancing . International Journal of Clinical Practice. https://doi.org/10.1111/ijcp.13501 
Sung, F., Yang, Y., Zhang, L., Xiang, T., Torr,

P. H. S., \& Hospedales, T. M. (2018).

Learning to Compare: Relation Network

for Few-Shot Learning. In Proceedings of

the IEEE Computer Society Conference on

Computer Vision and Pattern Recognition.

https://doi.org/10.1109/CVPR.2018.00131

Tomkins, L., \& Ulus, E. (2015). 'Oh, was that “experiential learning”?!' Spaces, synergies and surprises with Kolb's learning cycle. Management Learning. https://doi.org/10.1177/135050761558745 1

Wang, J., Ren, F., Yu, J., Copeland, L., Wang, S., \& Wang, S. (2019). Toward a Better Understanding of Different Dissolution Behavior of Starches in Aqueous Ionic Liquids at Room Temperature. ACS Omega. https://doi.org/10.1021/acsomega.9b00962

Welton, T. (2018). Ionic liquids: a brief history. Biophysical Reviews. https://doi.org/10.1007/s12551-018-04192

Yulianti, I., Hamidah, I., \& Komaro, M. (2020). Green Chemistry principle: Ionic Liquids as a material teaching for vocational students. In IOP Conference Series: Materials Science and Engineering. https://doi.org/10.1088/1757899X/850/1/012047

Zhang, S., Sun, N., He, X., Lu, X., \& Zhang, X. (2006). Physical properties of ionic liquids: Database and evaluation. Journal of Physical and Chemical Reference Data. https://doi.org/10.1063/1.2204959 